\title{
The Energy Produced By 150 Watt Monocrystalline Solar Panels In Metro City
}

\author{
Muhammad Barkah Salim ${ }^{1}$, Novita Intan Kusuma Dewi ${ }^{2}$, Nyoto Suseno ${ }^{3}$ \\ Physics Education, Universitas Muhammadiyah Metro, Indonesia ${ }^{1,2,3}$ \\ barkah_um@yahoo.co.id ${ }^{1}$, novitaintan48@gmail.com ${ }^{2}$, nyotoseno@gmail.com ${ }^{3}$ \\ Received: December $3^{\text {rd }}$, 2019. Revised: May $4^{\text {th }}, 2020$. Accepted: May $9^{\text {th }}, 2020$
}

\author{
Keywords : \\ Solar Panel; Energy; \\ Experimental Research
}

\begin{abstract}
Researchers have conducted research on the energy produced by 150 watt solar panels in the city of metro. This research was conducted because many solar panels have been made, but it has not yet been identified how much energy is actually produced. In addition, to find out whether the city of metro is feasible to use solar panels. The purpose of this study was to determine the energy produced by 150 watt solar panels in the city of metro. The research method used is experimental research. Researchers conducted for five days from 08.00 AM to 04.00 PM. After doing the research, it was found that the energy that could be produced in the solar panel in one day was 876,507 joule. The value of the effectiveness of solar panels in the city of metro has a value of $100 \%$ with criteria for proper use.
\end{abstract}

\section{INTRODUCTION}

Metro city is a beautiful little city. Around the area of the metro city is the mainland, so far from the effects of natural disasters such as earthquakes, landslides and tsunami. The geographical location of the metro city is $5^{\circ} 6^{\prime}-5^{\circ} 8^{\prime}$ south latitude and $105^{\circ} 17^{\prime}-105^{\circ} 19^{\prime}$ east longitude [1]. From its geographical location, the light entering the metro city area is very bright in the summer and quite bright during the rainy season. with this condition makes the city of the metro into a decent city to live in. With the state of the metro city bright because of exposure to sunlight, researchers have the desire to test how much energy is produced per day. hope with this research, the citizens of the city of the metro can find out whether solar energy can be used as substitute energy.

According to Walisiewicz, energy in life has many types [2]. But what we can find in our daily lives are several, namely solar energy, geothermal energy, chemical energy, electrical energy and nuclear energy. The other forms of energy are the energy of water motion and wind energy. Of the several types of energy forms, some energy can be produced without limits, namely solar energy, motion energy in water, and motion energy in water. Energy can be changed from one form to another [3]. The statement is the sound of the law of conservation of energy. If humans want to use energy, then unlimited energy is very good if it is utilized to the full.

The current use of fossil energy is quite alarming. Harjanto states that the energy needs of 2025 will be four times that of 2000 [4]. The use of fossil energy that cannot be renewed will have an impact on 
resources, climate and the environment. Therefore, the development and utilization of renewable energy must start in the community. The role of the government in driving the use of renewable energy with the issuance of government regulation No. 79 of 2014 concerning the National Energy Policy, the use of EBT is a priority, while fossil-based energy such as solar and coal is minimized. In the general plan for the supply of electricity (RUPTL) 2018-2027, the contribution of EBT in the energy mix for electricity generation is targeted to increase by 23 percent in 2025 [5].

The statement above is the background of why researchers conduct renewable energy research. The research focus is on the use of 150 watt solar panels to produce energy in the city of Metro. As for some researchers who have conducted research on the use of solar energy, Salim and Rajabiah examined the ability of a 150 watt solar panel on the current and charging generated [6]. The results of the study found that the current produced by the solar panel is 150 watts when it is cloudy, 0.6-0.8 amperes, cloudy 0.91.9 amperes and 2.0-3.2 amperes. while the charging time is $8-9 \%$ per hour.

Sunaryo has conducted research about renewable energy solar panels through simple experiments for high school Students and draws the conclusion that light intensity affects the amount of current, voltage, and power produced by solar panels [7]. Because the intensity is very influential in producing currents, voltage, and power produced by solar panels, researchers will do it when the sky is clear for 7 days. By doing it for 7 days, the average value of energy produced in one day is obtained.

From the above statement, the purpose of this study is to determine the effectiveness of solar panels in producing energy, the average energy produced in 1 day of charging, knowing when the time is most effective and ineffective.

\section{Energy}

Energy is a form that can be felt but is very difficult to prove. An example is the sun's rays, the heat generated from the light emitted can be felt by our skin, but cannot be touched. Energy is a quantity derived from units of joules. According to the law of conservation of energy, energy cannot be created or destroyed. Energy can only be changed from one form to another. One example of this form of energy change is that light energy is converted into electrical energy using solar panels [8].

According to another understanding, energy is the ability to do work [9]. Things that cause work include moving cars from one place to another, moving tables from the living room to the kitchen, leaves that fly from one place to another because of the air, and others.

\section{Solar Energy}

The sun is one source of energy that is very potential for human needs. The sun's energy can be obtained from the heat that propagates to the surface of the earth and the light that illuminates the surface of the earth. Some research states that by changing sunlight with solar cells can be made a source of electrical energy for human use in everyday life. The selection of this energy source is very reasonable given the supply of solar energy from sunlight reaching the earth's surface reaches $3 \times 1024$ joules per year. The amount of solar energy is equivalent to 10,000 times the world's current energy consumption. In Indonesia, abundant sunshine that can be captured evenly throughout the Indonesian archipelago for most of the year is a potential source of electrical energy. Sun intensity influences the amount of power, where if the intensity of low power produced is low while the intensity of high power produced will also increase [10].

\section{METHOD}

The research method that researchers do is the experimental method. This type of research is quantitative. Observations were made for 7 days in April 2019, namely at 08.00 AM - 04.00 PM local time. This research was located in an open space at the University of Muhammadiyah Metro, Jalan Ki Hajar Dewantara No. 116 Metro City. The tools and materials used include 150 watt monocrystalline solar panels, MPPT30 regulators, multimeters, 2 electric motor batteries, inverters, lux meters 
(LabQues), thermometers, watches, cellphone cameras, connecting cables.

The method of experimentation and data collection is first to make a series like in Figure 2. After everything is installed, put the solar panel under the sun and make sure it is not blocked by anything. After everything is ready, the MPPT30 regulator is turned ON. If the regulator has detected an inrush from the solar panel, the device is ready to use.

Data retrieval starts at $08.00 \mathrm{AM}$ and takes data every 15 minutes until $04.00 \mathrm{PM}$. The data taken is if the sky is clear, not cloudy or rainy. If it is cloudy or rainy, then data retrieval on that day is deleted and replaced with another day. The duration of data retrieval is 7 days in a clear condition. At the time of observation, the data generated is written in the form of diagrams and tables.

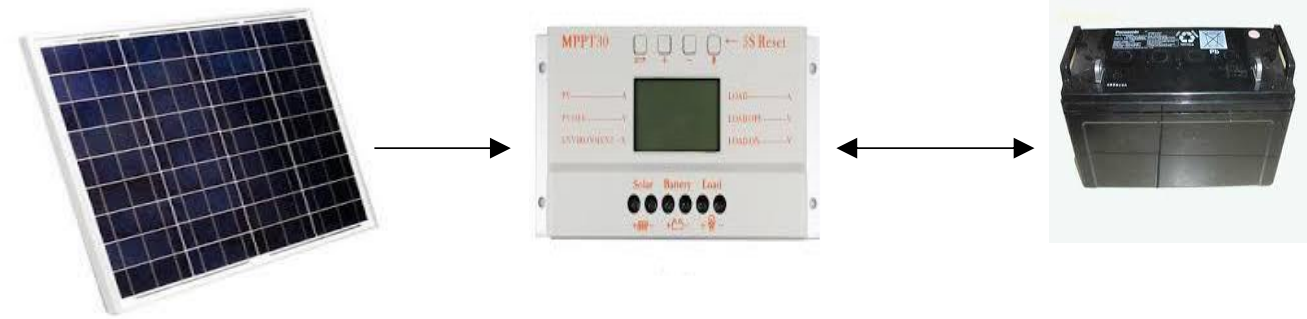

Fig 1. Series of experiments

The shape of the series of this study is shown in Fig 1 . The solar panel is placed in a place that is directly affected by light. The electrical energy produced by solar panels enters the regulator to be stored in the battery. The energy stored in the battery goes back to the regulator and is channeled to the output in the form of a DC current.

\section{RESULTS AND DISCUSSIONS}

After the researchers experimented for 7 days, data obtained as described in the statement below.

\section{Energy Produced}

Based on observations that have been made for 7 days, in April 2019, the total energy data per day can be seen in Table 1.

Table 1. Average Energy

\begin{tabular}{cc}
\hline Date & Total energy/day (Joule) \\
\hline April 1st 2019 & $1,014,912$ \\
April 2nd 2019 & 843,552 \\
April 8th 2019 & 869,760 \\
April 9th 2019 & $1,049,472$ \\
April 10th 2019 & 762,048 \\
April 15th 2019 & 781,344 \\
April 22nd 2019 & 814,464 \\
\hline Amount & $\mathbf{6 , 1 3 5 , 5 5 2}$ \\
\hline Avrage & $\mathbf{8 7 6 , 5 0 7}$ \\
\hline
\end{tabular}

In Table 1 the data is taken for 7 days. From the first data to the seventh data is not the same, because the conditions of each day are still equally bright, but still different. That is the reason why researchers 
take data more than once so that the data obtained can approach the true value. Retrieval of data by researchers is every 15 minutes, starting at 08:00 AM - 04:00 PM. The amount of energy per day obtained by researchers is on April $9^{\text {th }}, 2019$ with the energy generated at 1,049,472 joules. The smallest amount of energy is obtained on the stairs April $10^{\text {th }}, 2019$ with the energy produced by 762,048 joules. If the total energy is averaged over 7 days, 876,507 joules are obtained.

If from 08: $00 \mathrm{AM}$ - 04:00 PM is 28,800 seconds, the energy per second that can be used is 30.43 joules/second. This value is equivalent to 30.43 watts. So, if during the day you want to turn on the lights without using electricity PLN can use two lamps with a load of 15 watts or one lamp with a load of 30 watts.

Effectiveness of 150 Watt Solar Panels

Power generated using a 150 watt solar panel, obtained data as in Table 2.

Table 2. Power Generated

\begin{tabular}{cc}
\hline Date & Average Power (Watt) \\
\hline April 1st 2019 & 35.24 \\
April 2nd 2019 & 29.29 \\
April 8th 2019 & 30.20 \\
April 9th 2019 & 36.44 \\
April 10th 2019 & 27.53 \\
April 15th 2019 & 27.13 \\
April 22nd 2019 & 28.28 \\
\hline Amount & $\mathbf{2 1 4 . 1 1}$ \\
\hline Average & $\mathbf{3 0 . 5 8}$ \\
\hline
\end{tabular}

In table 2, it appears that the power produced ranges from 27-36 watts. The size of the resulting value depends on the brightness of the sky due to clouds or not. If calculated the average power produced for 7 days, obtained data of 30.58 watts. According to Parastiwi, monocrystalline solar panels have an efficiency of $15 \%-20 \%$ of the panel's maximum power [11]. So, if a 150 watt solar panel can produce an average power of 30.58 watts, then the efficiency of the solar panel is equal to :

$$
\begin{aligned}
& \text { Efficiency }=\frac{\text { average value }}{\text { maximum value }} \times 100 \% \\
& \text { Efficiency }=\frac{30.58 \text { watt }}{150} \times 100 \%
\end{aligned}
$$

$$
\text { Efficiency }=20.38 \%
$$

From the values obtained, the power generated by 150 watt solar panels in the city of metro has very good efficiency.

\section{Effective and Ineffective Time}

Look at the data as shown in Figure 2. Figure 2 is the average data per hour for 7 days researchers take data. Researchers collected data from 08.00 AM - 04.00 PM. The time range of data collection is 15 minutes. 


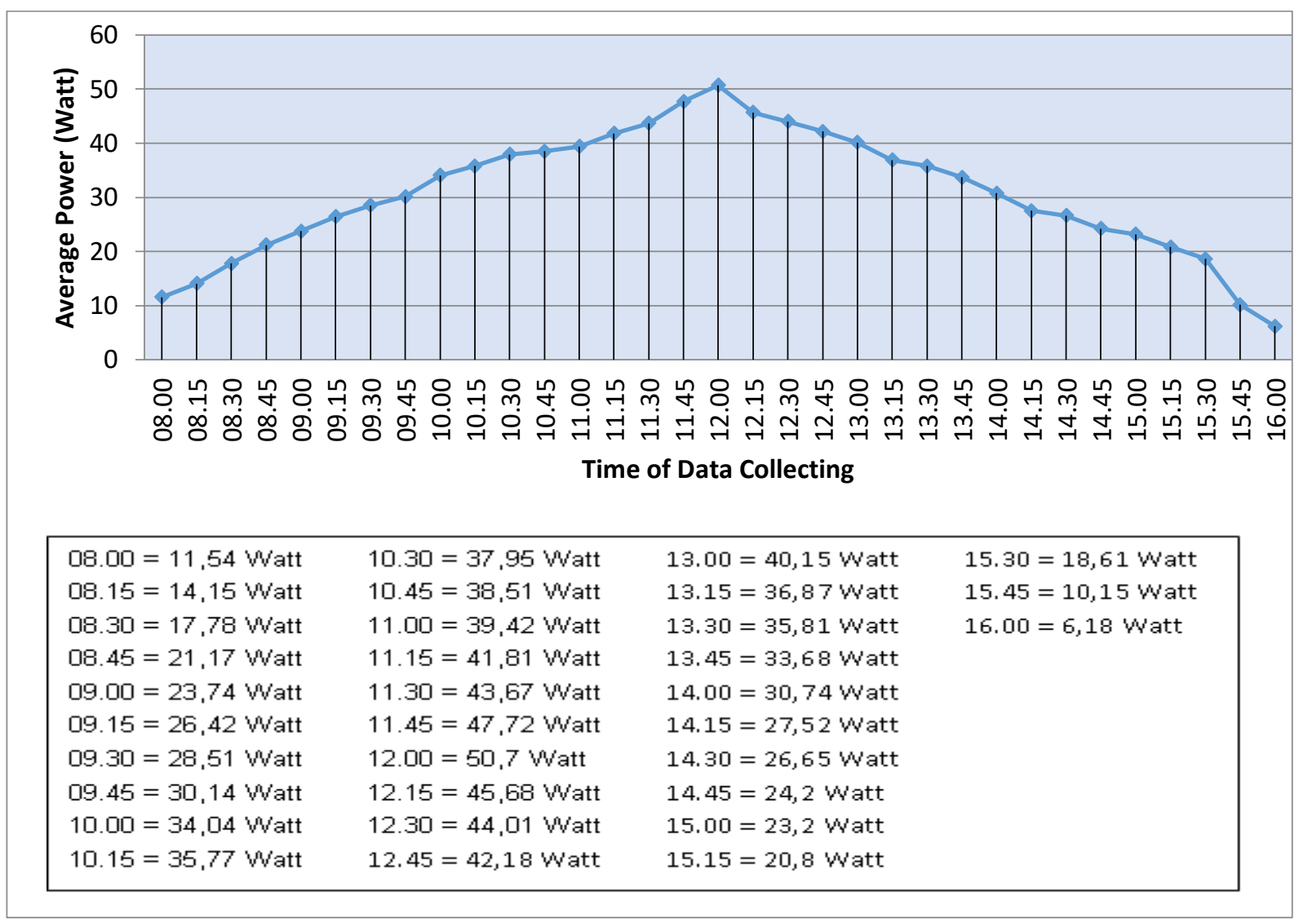

Fig 2. Graph of power versus time

In Fig 2 it appears that the power generated from starting at $08.00 \mathrm{AM}$ values continues to rise until 12:00 PM. After that, the value drops again constantly until 04:00 PM. The highest power is generated at $12.00 \mathrm{PM}$ that is when the sun is directly above us. The power that can be produced at $12.00 \mathrm{PM}$ is 50.7 watts. If you look at the data as in Fig 2, the most effective time to get enough power is from starting at $08.45 \mathrm{AM}-03.15 \mathrm{PM}$. because the power that can generate the inverter is above 20 watts. Less and more than that is time ineffective.

\section{CONCLUSION AND SUGGESTION}

From what has been explained, the conclusion of this research is, the energy that can be produced by a 150 watt solar panel in one day is equal to 876,507 joules/day. The use of 150 watt solar panels in Metro City has a very good efficiency that is equal to $20.38 \%$, so the metro city is feasible to use solar panels. The most effective time to produce power is at $08.45 \mathrm{AM}-03.15 \mathrm{PM}$, with the highest power generated at 12.00 PM.

The advice that researchers can give is, try to build solar panels in the direction of the sun. Before making data retrieval, always try to clean the surface of the solar panel from dirt so that it does not block incoming light. Store solar panels in a dry place so that mold does not appear on the surface.

\section{ACKNOWLEDGMENTS}

The researcher would like to thank the UM Metro Physics Education Laboratory for facilitating the use of tools. Researchers also say many thanks to a teammate because with their help this research can be completed on time. 


\section{REFERENCES}

[1] BPS Kota Metro. (2018). Kota Metro Dalam Angka. BPS Kota Metro.

[2] Walisiewicz, M. (2002). Energi Alternatif. Jakarta: Erlangga.

[3] Halliday, D. (2010). Fisika Dasar. Jakarta: Erlangga.

[4] Harjanto, N. T. (2016). Dampak lingkungan pusat listrik tenaga fosil dan prospek pltn sebagai sumber energi listrik nasional. PIN Pengelolaan Instalasi Nuklir, 1(01).

[5] Latief. (2018). Pemerintah Terus Dorong Pemakaian Energi baru dan Terbarukan. [Online]. Available: https://ekonomi.kompas.com/read/2018/09/21/203200526/pemerintah-terus-dorongpemakaian-energi-baru-dan-terbarukan.

[6] Salim, M. B., \& Rajabiah, N. (2019). Analisis Kemampuan Panel Surya Monokristalin 150 Watt pada Arus dan Pengisian yang Dihasilkan. JIPFRI (Jurnal Inovasi Pendidikan Fisika Dan Riset Ilmiah), 3(1): 29-35.

[7] Sunaryo, S., Budi, A. R., Ruliana, R., \& Kholimah, S. (2015). Kajian Fisis Energi Terbarukan Panel Surya Melalui Eksperimen Sederhana untuk Siswa SMA. Jurnal Penelitian \& Pengembangan Pendidikan Fisika, 1(2): 81-88.

[8] Iskandar, S., \& Djuanda. (2017). Konversi Energi, 1st ed. Yogyakarta: DEEPUBLISH.

[9] Saripudin, A. (2008). Fisika, 2A ed. Bandung: Grafindo.

[10] Yuliananda, S., Sarya, G., \& Hastijanti, R. R. (2015). Pengaruh perubahan intensitas matahari terhadap daya keluaran panel surya. JPM17: Jurnal Pengabdian Masyarakat, 1(02).

[11] Parastiwi, A., Putri,, R. I., Adhisuwignjo, S., \& Rifa, M. (2018). Photovoltaic Terapan: Photovoltaic Terapan (Vol. 1). UPT Percetakan dan Penerbitan Polinema. 